\title{
DINAMIKA FUNGSI KEPOLISIAN DAN HUBUNGANNYA DENGAN PROGRAM PERPOLISIAN MASYARAKAT
}

\author{
Wahyono \\ Fakultas Hukum Universitas Bhayangkara Surabaya \\ e-mail:wahyono_baskoro@yahoo.co.id
}

\begin{abstract}
ABSTRAK
Sejak terpisahnya institusi Polri dengan TNI, banyak pembaharuan telah dilakukan, antara lain membuat konsep pendekatan baru terhadap masyarakat dalam melaksanakan tugas pengayoman dan pembinaan terhadap masyarakat. Dengan program POLMAS diharapkan akan tercipta sistem situasi keamanan dan ketertiban yang kondusif, karena masyarakat akan menyadari bahwa ketertiban dan keamanan itu tidak mungkin tercipta tanpa kerjasama yang sinergis antara Polri dengan masyarakat. Dalam program ini diharapkan akan tercipta keikutsertaan masyarakat dalam menanggulangi setiap ancaman, gangguan, hambatan, baik berupa pelanggaran maupun kejahatan yang akan mengganggu ketertiban dan keamanan masyarakat.
\end{abstract}

Kata Kunci: dinamika, fungsi kepolisian, program perpolisian masyarakat.

\begin{abstract}
Since being apart between institution of Indonesian Police (POLRI) with Indonesian National Armed Forces (TNI), there are so many renewals have been done, such as: making new approach concept prominently for sheltering and establishing society. By having this POLMAS program, it is expected to create a conducive, peaceful and orderly situation system because society will realize that safety and orderliness situation will be impossible without any synergy cooperation between POLRI and society. It is also expected that this program will create the participation of society to cope every threat, attack, and obstacle, in the form of violation or criminal which will disturb a peaceful and orderly system of society.
\end{abstract}

Keywords: dinamics, police function, society police program.

\section{PENDAHULUAN}

Salah satu tujuan Negara Indonesia yang ditetapkan dalam Pembukaan Undang-Undang Dasar 1945 adalah melindungi segenap bangsa Indonesia dan seluruh tumpah darah Indonesia. Selanjutnya guna mewujudkan tujuan mulia tersebut Negara membentuk institusi khusus, diantaranya institusi Polri sebagai alat negara yang menjaga keamanan dan ketertiban masyarakat yang bertugas melindungi, mengayomi dan melayani masyarakat serta menegakkan hukum yang lebih lanjut dipertegas dengan UndangUndang Kepolisian Negara Republik Indonesia bertujuan untuk mewujudkan keamanan dalam negeri dengan tugas pokok (Pasal 4 dan 13 Undang-Undang No. 2 Tahun 2002): a. Memelihara Keamanan dan Ketertiban Masyarakat; b. Menegakkan hukum; c. Memberi perlindungan, pengayoman dan pelayanan kepada masyarakat.

Diakui bahwa selama, ini citra Polri di mata masyarakat tidaklah terlalu baik, hal ini disebabkan adanya tingkah laku dari segelintir dari oknum Polri yang semestinya bertindak sesuai tugas pokoknya namun gara-gara segelintir oknum tersebut yang menyimpang, maka masyarakat menggeneralisir terhadap citra institusi Polri. Masyarakat dewasa ini masih bersikap mendua, disatu sisi bila ada razia Polisi sebagian masyarakat menggerundel sembari berkata "Polisi lagi", sebaliknya bila terjadi kemacetan lalu lintas mereka justru butuh polisi, lagi-lagi dengan kata gerundel "mana sih polisinya?"

Polri dengan paradigma barunya bertekad meminimalis citra buruknya sehingga masyarakat akan selalu mendambakan sosok polisi sesuai visi dan misinya yaitu: Terwujudnya postur Polri yang profesional, bermoral dan modern sebagai Pelindung, Pengayom dan Pelayan masyarakat yang terpercaya dalam memelihara Keamanan dan Ketertiban Masyarakat dan Menegakkan hukum.

Paradigma baru Polri tidak terlepas dari kenyataan bahwa Polri perlu kembali pada doktrin awal yaitu "Tata Tentrem Kerta Raharja" yang dalam kiprahnya terjadi pasang surut perjalanannya sebagaimana tergambar berikut: (Semeru 371, 2007) a. Kepolisian Indonesia menjelang Proklamasi Kemerdekaan 17 
Agustus 1945 adalah Kepolisian dari pendudukan tentara Jepang yang membagi 2 (dua) lingkungan Kepolisian yaitu: 1. Lingkungan Kepolisian Sumatra, Jawa-Madura di bawah kendali Angkatan Darat Jepang yang berpusat di Jakarta, serta 2. Lingkungan Kepolisian bagian Timur dan Kalimantan di bawah kendali Angkatan Laut berpusat di Makasar. Pasca Proklamasi kemerdekaan Indonesia 17 Agustus 1945, maka pada tanggal 1 Oktober 1945 berdasarkan Maklumat Pemerintah diputuskan pembentukan Jawatan Kepolisian dengan memasukkan badan-badan Kepolisian ke dalam lingkungan Departemen Dalam Negeri dan mengangkat RS. Sukanto Tjokrodiatmojo sebagai Kapolri; b. Berdasarkan Penetapan Pemerintah Nomor: 11/80/1946 tanggal 1 Juli 1946 Polri menjadi Jawatan kepolisian Negara tersendiri di bawah Perdana Menteri; c. Berdasarkan Penetapan Dewan Pertahanan Negara nomor: 112/Tahun 1947 tanggal 1 Agustus 1947 Kepolisian Negara didemiliterisasi dan penyesuian pangkat disamakan dengan Pangkat Ketentraman dan pemberlakuan tata tertib Peraturan Militer dalam Undang-Undang Nomor: 40 tahun 1947 sedangkan Polisi yang menjalankan tugas pengusutan perkara di bawah pengawasan Jaksa Agung; d. Berdasarkan Peraturan Pemerintah Nomor: 01/Tahun 1948 tanggal Februari 1948 Polri berstatus Jawatan Kepolisian Negara di bawah Presiden dan e. Berdasarkan Penetapan Presiden Nomor: 01 Tahun 1949 tanggal 15 Mei 1949 Polri berstatus Kepolisian Negara Pemerintahan Militer di bawah Kementerian Pertahanan; f. Berdasarkan Penetapan Presiden RIS Nomor: 22 Tahun 1950 tanggal 16 Januari 1950 Polri berstatus Jawatan Kepolisian Negara di bawah Perdana Menteri melalui Menteri Pertahanan; g. Berdasarkan Penetapan Perdana Menteri Nomor: 03 PM/1950 tanggal 27 Januari 1950 dengan kebijakan politik polisionil dalam rangka pemusatan kepolisian dan Angkatan Perang dalam satu tangan maka Polri berstatus Kepolisian Negara di bawah Perdana Menteri melalui Menteri Pertahanan; h. Berdasarkan Keppres Nomor: 154/Tahun 1959 tanggal 15 Juli 1959 serta Surat Edaran Menteri Pertama nomor: 01/MP/ 1959 tanggal 26 Agustus 1959 status Polri setingkat departemen menjadi Departemen Kepolisian yang dipimpin Menteri Muda Kepolisian; i. Berdasarkan Tap MPRS Nomor: H/NTRS/1960 serta Keppres Nomor 21 Tahun 1960 memperkuat status Kepolisian menjadi Departemen Kepolisian; j. Berdasarkan Keppres Nomor: 134 Tahun 1962 tanggal 12 April 1962 sebutan Kepolisian Negara menjadi Angkatan Kepolisian RI yang dipimpin oleh Menteri/Kepala Staf Angkatan Kepolisian di bawah Koordinator
Menko Pertahanan dan Keamanan; k. Berdasarkan Keppres Nomor 15 Tahun 1963 tanggal 30 Januari 1963 mengubah sebutan Menteri Kepala Staf Angkatan Kepolisian menjadi Menteri/Panglima Angkatan Kepolisian (Men/Pangak) di bawah Koordinator Menko Hankam; 1. Berdasarkan Keppres Nomor: 290/Tahun 1964 tanggal 12 Nopember 1964 integrasi Angkatan Kepolisian secara penuh sebagai unsur ABRI di bawah koordinator Menko Hankam; m. Berdasarkan Keppres nomor: 132 Tahun 1967 tanggal 24 Agustus 1967 Menteri/Panglima Angkatan Kepolisian (Men/Pangak) menjadi Panglima Angkatan Kepolisian (Pangak) di bawah koordinator Menhankam/Pangab; n. Berdasarkan Keppres Nomor: 52 Tahun 1969 tanggal 27 Juni 1969 terjadi perubahan sebutan dari Pangak kembali menjadi sebutan Kapolri dengan status sebagai unsur ABRI di bawah struktur Menhankam/Pangab sekaligus pemberlakuan doktrin perjuangan ABRI; o. Berdasarkan pasal 29 dan 30 Undang-Undang Nomor: 20 tahun 1982 tentang Hankam negara mengokohkan kedudukan Kepolisian Negara RI sebagai bagian unsur ABRI yang berkedudukan di bawah Menhankam/Pangab; . Berdasarkan Kebijakan Pemerintah melalui Instruksi Presiden (Inpres) Nomor 2 tahun 1999 tanggal 1 April 1999 tentang pemisahan Kepolisian RI dari TNI dan sementara berada di bawah Dephankam; q. Berdasarkan Tap MPR Nomor: VI/MPR/2000 dan Tap MPR Nomor: VII/MPR/2000 tanggal 18 Agustus 2000 tentang Pemisahan Peran TNI dan Polri, selanjutnya menempatkan kedudukan Polri mandiri langsung di bawah Presiden.

Perkembangan sosial dan dalam masyarakat transisi saat ini sangat mempengaruhi kinerja polisi dalam rangka penegakan hukum sebagai proses yang akan berlangsung terus-menerus. Disatu sisi bisa menjadi pendukung pelaksanaan tugas polisi tetapi disisi lain bisa menjadi ancaman, tantangan, hambatan dan gangguan yang justru baru dihadapi dan ditanggulangi oleh polisi dan oleh kekuatan rakyat yang mendukung. Polisi dalam hal ini Kepolisian Negara Republik Indonesia (Polri) salah satu unsur criminal justice system di Indonesia.

Terkait dalam penegakan hukum (selain jaksa dan hakim). Polri bertindak harus sesuai dan berdasarkan peraturan perundang-undangan yang berlaku. Prinsip inilah yang sesungguhnya melekat pada tugas penegakan hukum termasuk oleh Polri.

Dalam masyarakat sipil yang modern, setiap masyarakat dituntut untuk berproduksi dan berguna atau setidak-tidaknya dapat menghidupi dirinya sendiri serta dapat saling menghidupi satu sama 
lainnya dalam kehidupan bermasyarakat. Mereka yang tidak berproduksi dianggap sebagai beban atau benalu masyarakat. Dalam kenyataannya proses tersebut tidak selalu berjalan dengan lancar namun juga terdapat gangguan-gangguan (dapat berupa tindak kejahatan maupun kerusuhan sosial) yang dapat menghentikan, merusak atau bahkan menghancurkan produktivitas masyarakat. Agar dalam jalannya produksi yang mensejahterahkan masyarakat tersebut jangan sampai terganggu atau hancur, maka diperlukan adanya aturan, norma atau hukum yang adil dan beradab.

Untuk menegakkan hukum dan aturan tersebut, mengajak masyarakat untuk mematuhi dan melaksanakannya, serta untuk memelihara keteraturan sosial, diperlukan adanya institusi yang dapat bertindak sebagai wasit yang dipercaya, adil, dan beradab. Institusi tersebut dapat berfungsi untuk menjaga atau melindungi jalannya produktivitas, serta dalam upaya menjamin keberadaan manusia dan masyarakatnya. Salah satunya adalah institusi kepolisian.

Sebagai konsekuensi dari hal-hal yang diuraikan di atas, maka orientasi polisi untuk menciptakan suatu kondisi keamanan dan ketertiban dalam masyarakat diperlukan kepolisian yang dapat dipercaya oleh masyarakatnya. Dalam hal ini adalah polisi yang penerapannya mengacu pada acuan dasar demokrasi, dan menyesuaikan dengan corak budaya masyarakat maupun kebudayaannya. Hal tersebut dapat ditunjukkan dengan adanya hubungan yang dinamis antara masyarakat dengan petugas kepolisian. Mereka dapat bekerjasama dalam menyelesaikan berbagai masalah sosial yang terjadi di masyarakat khususnya masalah keamanan. Serta dalam menerapkan program pemolisiannya juga berdasarkan pada supremasi hukum yang berlaku, senantiasa dapat menjamin dan memberikan perlindungan Hak Asasi Manusia (HAM). Disamping itu perlu adanya transparansi atau keterbukaan sebagai bentuk pertanggungjawaban publik, serta pembatasan dan pengawasan kewenangan pada polisi.

Dengan demikian maka prioritas pemolisiannya adalah memberikan pelayanan yang berorientasi pada masyarakat yang dilayaninya, dan tidak hanya melihat dari sisi kepolisian saja melainkan juga melihat pemolisian tersebut, tidak lagi dilakukan semata-mata membawa instruksi dari atas yang bersifat reaktif atau menunggu laporan pengaduan perintah (top down), melainkan dilakukan secara proaktif dan senantiasa menumbuh kembangkan kreativitas atau inovasi-inovasi baru dalam menyelesaikan berbagai masalah sosial yang terjadi dalam masyarakat (bottom up).
Kepolisian Negara Republik Indonesia saat ini menerapkan dan mengembangkan perpolisian masyarakat (community policing), sesuai Skep Kapolri No. Pol. Skep: Skep/737/X/2005 tanggal 13 Oktober 2005 tentang Kebijakan dan Strategi Penerapan Model Perpolisian Masyarakat dalam Penyelenggaraan Tugas Polisi sebagai alternatif pemolisian, yang berorientasi pada masyarakat dalam memelihara ketertiban. Dalam hal ini polisi bersama-sama dengan masyarakat untuk mengidentifikasi dan menyelesaikan berbagai masalah yang terjadi dalam masyarakat. Dalam pemolisiannya polisi senantiasa berupaya mengurangi rasa ketakutan masyarakat akan adanya gangguan krimi nalitas (reduce fear of crime), serta lebih mengedepankan pencegahan kejahatan (crime prevention), dan juga berupaya ikut serta untuk meningatkan kualitas hidup masyarakatnya (increase quality of live).

Atas dasar dari uraian tersebut di atas, maka dapatlah dirumuskan permasalahan sebagai berikut: a. Bagaimana eksistensi Perpolisian Masyarakat saat ini yang merupakan strategi baru di tubuh kepolisian?; b. Mampukah Perpolisian Masyarakat menciptakan keamanan dan ketertiban masyarakat yang kondusif?

\section{EKSISTENSI PERPOLISIAN MASYARAKAT YANG MERUPAKAN STRATEGI BARU DI TUBUH KEPOLISIAN \\ Konsep Perpolisian Masyarakat}

Konsep Perpolisian Masyarakat diluncurkan terutama di negara-negara yang maju, penyelenggaraan tugas-tugas Kepolisian, baik dalam pemeliharaan keamanan dan ketertiban maupun penegakan hukum dilakukan secara konvensional. Polisi cenderung melihat dirinya sebagai alat negara sehingga, pendekatan kekuasaan bahkan tindak represif seringkali mewarnai pelaksanaan tugas dan wewenang kepolisian (Polda Jatim, 2006). Walaupun prinsip-prinsip "melayani dan melindungi (to serve and to protect)" ditekankan, pendekatan yang birokratis, sentralistik, serba sama atau seragam mewarnai layanan kepolisian. Gaya perpolisian tersebut mendorong polisi untuk mendahulukan mandat dari pemerintah pusat dan mengabaikan persetujuan masyarakat lokal yang dilayani. Selain itu polisi cenderung menumbuhkan sikap yang menampilkan dirinya sebagai sosok yang formal berakibat pada memudarnya legitimasi kepolisian di mata publik pada satu sisi, serta semakin berkurangnya dukungan publik bagi pelaksanaan tugas Kepolisian maupun buruknya citra polisi pada sisi lain.

Di Indonesia, lebih-lebih ketika Polri disajikan sebagai bagian integral ABRI dan Polisi merupakan 
prajurit ABRI yang dalam pelaksanaan tugasnya diwarnai sikap dan tindakan yang kaku bahkan militeristik yang tidak proporsional. Perpolisian semacam ini juga ditandai antara lain oleh pelaksanaan tugas Kepolisian, utamanya penegakan hukum yang bersifat otoriter, kaku, keras dan kurang peka terhadap kebutuhan rasa aman masyarakat. Disisi lain pelaksanaan tugas kepolisian sehari-hari, lebih mengedepankan penegakan hukum utamanya untuk menang menanggulangi tindak kriminal. Polri dibebani tugas melakukan pembinaan kamtibmas yang diperankan oleh Babinkamtibmas sebagai ujung tombak terdepan. Pendekatan demikian memposisikan masyarakat seakan ujung tombak terdepan. Pendekatan demikian memposisikan masyarakat seakan-akan hanya sebagai objek dan polisi sebagai subjek yang serba lebih sehingga dianggap figur yang mampu dan menyelesaikan segenap permasalahan yang dihadapi masyarakat.

Sejalan pergeseran peradaban umat manusia secara universal terutama di negara maju, masyarakat cenderung semakin jenuh dengan cara lembaga pemerintah yang birokratis, resmi, formal, general dan lain-lain dalam, menyajikan layanan publik. Terdapat kecenderungan bahwa masyarakat lebih menginginkan pendekatan-pendekatan yang personal dan menekankan pemecahan masalah daripada terpaku pada masalah formalitas hukum yang kaku. Dalam bidang pembinaan hukum terutama yang menyangkut pertikaian antarwarga, penyelesaian dengan mekanisme informal dipandang lebih aktif daripada proses peradilan pidana formal yang acapkali kurang memberikan peranan yang berarti bagi korban dalam pengambilan keputusan.

Kondisi di atas mendorong diluncurkannya program baru dalam penyelenggaraan tugas kepolisian yaitu Community Policing tidak lagi hanya merupakan suatu program dan/atau strategi melainkan suatu falsafah yang menggeser paradigma konvensional menjadi suatu model perpolisian baru dalam masyarakat madani. Model ini pada dasarnya menempatkan masyarakat bukan semata-mata sebagai objek tetapi mitra kepolisian dan pemecahan masalah (pelanggaran hukum) lebih merupakan kepentingan dari pada sekedar proses penanganan yang formal atau prosedural. Paradigma yang ideal bagi Polri yaitu: a) Polri sebagai polisi sipil yang profesional, modern dan bermoral; b) Budaya polisi sipil adalah suatu orientasi berfikir dan bertindak polisi yang terdiri dari nilai perspektif dan ideologi tentang sikap dan tingkah laku polisi yang sejalan dengan orientasi bersikap dan bertindak masyarakat Indonesia; c) Membangun polisi berkarakter sipil, memperlakukan masyarakat sebagai orang sipil namun juga bagaimana polisi bertindak sebagai orang sipil; d) Budaya polisi sipil masih berada dalam tataran konseptual saja dan perlu dijabarkan lebih lanjut dalam tataran operasional seperti: pembenahan tata nilai, penataan kembali budaya organisasi, peningkatan profesionalisme mencakup peningkatan knowledge, skill, dan moral and ethical values; e) Tindakan-tindakan pembenahan di tingkat nasional meliputi: pola rekrutmen anggota Polri; pemenuhan dana operasi; peningkatan gaji bintara sampai perwira peningkatan sarana atau prasarana; peningkatan fungsi pengawasan; f) Struktur tetap berada langsung di bawah Presiden, dengan mengedepankan fungsi pengawasan melalui Komisi Kepolisian Nasional.

Dalam kehidupan bermasyarakat nilai-nilai yang terkandung dalam konsep Community Policing pada hakekatnya bukan hal yang asing. Kebijakan Siskamswakarsa diangkat dari nilai sosiokultural masyarakat Indonesia, yang lebih menjunjung nilai sosial daripada individu. Pelaksanaan pengamanan lingkungan secara swakarsa pernah atau masih efektif berjalan. Pada bagian-bagian wilayah desa atau kelurahan tertentu nilai-nilai kultural masih efektif (bisa diefektifkan) dalam penyelesaian masalah sosial pada tingkat lokal. Nilai saling memaafkan dijunjung tinggi dalam masyarakat Indonesia yang pada umumnya religius.

\section{Pengertian Polmas}

Konsep Polmas mengandung 2 (dua) unsur, Perpolisian dan Masyarakat. Secara harafiah perpolisian yang merupakan terjemahan dari kata "Policing" berarti segala hal ihwal tentang penyelenggaraan fungsi kepolisian. Dalam konteks ini perpolisian tidak hanya menyangkut hal-hal yang bersifat operasional (taktik/teknik) tetapi juga pengelolaan fungsi kepolisian secara menyeluruh mulai dari tataran manajemen puncak sampai manajemen lapis bawah.

Masyarakat yang merupakan terjemahan dari kata "Communist" (komunitas) dalam konteks Polmas berarti kepada siapa fungsi kepolisian disajikan (Public Service) dan dipertanggung jawabkan (Public Accountability) mengandung pengertian yang luas (society) yang mencakup setiap orang tanpa mempersoalkan status kewarganegaraan dan kependudukannya. Secara khusus masyarakat dapat diartikan berdasarkan dua sudut pandang, yaitu: a) Wilayah (Community of Geography). Warga masyarakat atau komunitas yang berada di dalam suatu wilayah kecil yang jelas batas-batasnya (geographic-community). 
Batas wilayah komunitas ini harus dilakukan dengan memperhatikan keunikan karakteristik geografis dan sosial dari suatu lingkungan dan terutama keefektifan pemberian layanan kepada warga masyarakat. Wilayah tersebut dapat berbentuk RT, RW, Kelurahan ataupun berupa Pasar/Pusat Perbelanjaan/Mall, Kawasan Industri, pusat/kompleks Olah Raga, Stasiun kereta Api, Terminal Angkutan, dan lain-lain, dan b) Kepentingan (Community of Interest). Dalam pengertian yang diperluas masyarakat dalam pendekatan Polmas diterapkan juga bisa meliputi sekelompok orang yang hidup dalam suatu wilayah yang lebih luas seperti kecamatan bahkan kabupaten atau kota, sepanjang mereka memiliki kesamaan kepentingan. Sebagai contoh berdasar profesi, hobi, etnis atau suku, agama, dan lain sebagainya.

Polisi Masyarakat adalah model penyelenggaraan fungsi kepolisian yang menekankan pendekatan kemanusiaan (humanistic approach) sebagai perwujudan dari kepolisian sipil dan yang menempatkan masyarakat sebagai mitra kerja yang setara dalam upaya penegakan hukum dan pembinaan keamanan dan ketertiban masyarakat.

a. Polmas sebagai Falsafah dan Strategi

Sebagai suatu falsafah Polmas mengandung suatu makna model perpolisian yang menekankan hubungan yang menjunjung tinggi nilai-nilai sosial atau kemanusiaan dan menampilkan sikap santun dan saling menghargai antara polisi dan warga dalam rangka menciptakan kondisi yang menunjang kelancaran penyelenggaraan fungsi kepolisian dan peningkatan kualitas hidup masyarakat.

Sebagai suatu Strategi, Polmas berarti model perpolisian yang menekankan kemitraan yang sejajar antara petugas polmas dengan masyarakat lokal dalam menyelesaikan dan mengatasi setiap permasalahan sosial yang mengancam keamanan dan ketertiban masyarakat serta ketentraman kehidupan masyarakat setempat dengan tujuan untuk mengurangi kejahatan dan rasa ketakutan akan kejahatan seta meningkatkan kualitas hidup warga setempat.

Dalam pengertian ini, masyarakat diberdayakan sehingga tidak lagi semata-mata sebagai objek dalam penyelenggaraan fungsi kepolisian melainkan sebagai subjek yang menentukan dalam mengelola sendiri upaya penciptaan lingkungan yang aman dan tertib bagi ketentraman dan keselamatan kehidupan bersama mereka yang difasilitasi oleh petugas kepolisian yang berperan sebagai petugas Polmas dalam suatu kemitraan. Dalam pengertian pengelolaan terkandung makna bahwa masyarakat berusaha menemukan, mengidentifikasi, menganalisis dan mencari jalan keluar pemecahan masalah-masalah gangguan keamanan dan ketertiban termasuk pertikaian antar warga serta penyakit masyarakat dan masalah sosial lain yang bersumber dari dalam kehidupan mereka sendiri bagi terwujudnya suasana kehidupan bersama yang damai dan tenteram.

Operasionalisasi konsep Polmas pada tataran lokal memungkinkan masyarakat setempat untuk memelihara dan menumbuhkembangkan sendiri pengelolaan keamanan dan ketertiban yang didasarkan atas norma-norma sosial dan atau kesepakatan-kesepakatan lokal dengan mengindahkan peraturan-peraturan hukum yang bersifat nasional dan menjunjung tinggi prinsip-prinsip Hak Asasi Manusia dan kebebasan individu yang bertanggung jawab dalam kehidupan masyarakat yang demokratis. Mengacu pada uraian di atas, Polmas pada hakekatnya mengandung dua unsur utama yaitu: a) Membangun kemitraan antara Polisi dan Masyarakat; dan b) Menyelesaikan berbagai masalah sosial yang terjadi dalam masyarakat.

b. Perwujudan Polmas

Sebagai strategi perwujudan Polmas dapat meng ambil bentuk berupa model wilayah dan kawasan. Disebut wilayah bila satu atau gabungan beberapa area atau kawasan pemukiman (RT/RW/Kelurahan/ Desa). Pembentukan Polmas model ini harus lebih didasari pada kehendak warga/tokoh masyarakat itu sendiri, walaupun dalam prosesnya bisa saja atas prakarsa dan dorongan polisi.

Sebagai kawasan bila satu kesatuan area kegiatan bisnis dengan pembatasan yang jelas, seperti mall/pusat perdagangan, pertokoan, perkantoran dan kawasan industri. Pembentukan Polmas model ini dapat diprakarsai oleh dan atas inisiatif bersama antara polisi dan tokoh masyarakat setempat.

\section{c. Prasyarat Pembentukan Polmas}

Perangkat yang merupakan prasyarat dalam pembentukan Polmas, meliputi pertama, Adanya seorang petugas Polmas yang ditugaskan secara tetap untuk model kewilayahan dan sejumlah petugas yang ditugaskan secara tetap untuk model kawasan; kedua, Model kawasan mempersyaratkan adanya "Pos" atau "Balai" sebagai pusat pelayanan kepolisian, sedangkan model wilayah dapat memanfaatkan fasilitas yang tersedia pada kantor kelurahan atau desa atau tempat tinggal petugas Polmas; ketiga, Adanya suatu forum kemitraan yang keanggotaannya mencerminkan keterwakilan semua unsur dalam masyarakat termasuk petugas Polmas dan pemerintah setempat.

Dalam pembentukan polmas harus dilakukan bersama-sama oleh tiga pilar utama Polmas, diantaranya unsur masyarakat yang dalam pembentukannya 
diwakili oleh tokoh-tokoh dan dalam operasionalisasinya oleh Forum Kemitraan Polisi dan Masyarakat (FKPM); Unsur Polri yang dalam pembentukannya diwakili oleh Kapolsek/staf dalam operasionalisasinya oleh Petugas Polmas yang ditunjuk dan dari Unsur Pemerintah daerah yang dalam pembentukannya diwakili oleh Camat/staf bersama Lurah/Kepala Desa/Badan Perwakilan Kelurahan/Desa dan dalam operasionalisasinya oleh Lurah/Kepala Desa.

d. Prinsip-prinsip Operasionalisasi Polmas

Prinsip-prinsip yang harus diwujudkan dalam operasionalisasi Polmas, meliputi: 1) Transparansi dan Akuntabilitas. Operasionalisasi Polmas oleh petugas polmas dan Forum Kemitraan Polisi dan Masyarakat harus dilakukan secara terbuka dan dapat dipertanggungjawabkan kepada masyarakat; 2) Partisipasi dan Kesetaraan. Operasionalisasi Polmas oleh petugas dan Forum Kemitraan Polisi Masyarakat harus dibangun atas dasar kemitraan yang setara dan saling membutuhkan, saling mendukung dengan menjamin keikutsertaan warga dalam proses pengambilan keputusan serta saling menghargai perbedaan pendapat; 3) Personalisasi. Petugas Polmas dituntut menciptakan hubungan yang dekat dan saling kenal serta memberikan layanan kepada setiap warga dengan lebih menekankan pendekatan pribadi dan pada hubungan formal; 4) Penugasan Permanen. Penempatan anggota Polri sebagai petugas Polmas merupakan penugasan permanen untuk jangka waktu yang cukup lama, sehingga memiliki kesempatan untuk membangun kemitraan dengan warga masyarakat di Kelurahan atau Desa; 5) Desentralisasi dan Otonomisasi. Pemberian kewenangan dan tanggung jawab kepada petugas Polmas dan Forum Kemitraan Polisi Masyarakat (FKPM) harus bersifat mandiri (otonom) dan independen dalam mengambil langkah-langkah pemecahan masalah dan penyelesaian tindak pidana ringan atau konflik antar warga maupun antara warga, polisi, dan pejabat setempat.

e. Prasyarat Keberhasilan

Keberhasilan operasionalisasi Polmas ditentukan oleh hal-hal sebagai berikut: 1) Perubahan persepsi di kalangan segenap anggota kepolisian setempat bahwa masyarakat adalah pemilik (Stakeholder) bukan saja kepada siapa polisi memberikan layanan tetapi juga kepada siapa mereka bertanggungjawab; 2) Pelaksanaan tugas anggota satuan fungsi operasional Polri harus dijiwai dengan semangat "Melayani dan Melindungi" suatu kewajiban profesi polisi.; 3) Perubahan pendekatan manajerial yang meliputi: a) Kapolsek bertanggungjawab untuk menunjang keberhasilan pelaksanaan tugas Polmas; b) Kapolres bersama staf terkait bertanggungjawab untuk mengusahakan dan menyediakan sumber daya dan dukungan yang diperlukan untuk pemecahan masalah; 4) Kerjasama dan dukungan Pemerintah Daerah/DPRD termasuk pemerintah desa serta komponen terkait yaitu instansi pemerintah beserta pengusaha. Lembaga-lembaga sosial kemasyarakatan (termasuk LSM) dan media massa (media cetak dan elektronik).

Kerjasama serta dukungan sebagaimana di atas menyangkut peran dan hal-hal sebagai berikut: a. Unsur Polri, meliputi: 1) Menyiagakan petugas Polmas terutama dengan memberdayakan Babinkamtibmas (lama) yang sudah dilatih dan diangkat secara khusus untuk jabatan tersebut; 2) Menyiapkan peralatan perlengkapan petugas Polmas termasuk barang-barang bekal untuk keperluan administrasi; 3) Mengusahakan dukungan anggaran serta dari instansi pemerintah lain seperti Bapenas, Depkeu dan Depdagri; 4) Menyediakan/menyalurkan dukungan anggaran petugas Polmas untuk tunjangan khusus atau fungsional dan biaya operasionalisasi; dan 5) Mengawasi dan mengarahkan operasionalisasi Polmas: $b$. Unsur masyarakat, meliputi: 1) Merangsang dan mendorong tumbuhnya minat dan kesadaran warga masyarakat untuk bekerja bersama membangun kemitraan dengan Polri dan Pemerintah Daerah/Desa/Kelurahan dalam memecahkan berbagai masalah sosial khususnya aspek ketertiban umum; 2) Mengusahakan/ ketersediaan lahan untuk lokasi pembangunan fasilitas pusat kegiatan Polmas sebagai Balai Kemitraan Polisi Masyarakat (BKPM); dan 3) Menjadi mitra aktif serta penyedia sumber daya manusia dan material, termasuk sukarelawan, tokoh adat, tokoh masyarakat tokoh agama untuk menangani berbagai masalah sosial dan kejahatan sehingga menjamin penyelesaian pertikaian antar warga pada tataran kehidupan masyarakat lokal dan timbulnya daya cegah jangka panjang; c. Unsur Pemerintah Daerah/Desa, meliputi: 1) Camat/staf bersama Pemerintah Desa Kelurahan dan Lembaga Perwakilan Desa atau Kelurahan diharapkan: mengambil langkah-langkah persiapan dalam pembentukan Polmas bersama Kapolsek atau staf; Memantau operasionalisasi Polmas dan mengkoordinasikan dengan unsur Polri dalam hal mengantisipasi adanya kendala yang dihadapi; Memberikan atau mengusahakan adanya dukungan dana, tenaga dan pemikiran untuk pemecahan berbagai masalah yang dikoordinasikan oleh FKPM dalam hal penggalangan dukungan Pemerintah; 2) Kepala Desa atau Lurah diharapkan menghadiri rapat-rapat FKPM dan ikut memberikan masukan jika diperlukan; dan 3) Pemerintah Daerah bersama Dewan Perwakilan 
Rakyat Daerah diharapkan: Menyediakan atau mengusahakan dukungan dana untuk biaya operasional (Rapat/Aktifitas) FKPM; Mengusahakan adanya dukungan alokasi anggaran untuk kegiatan atau proyek serta pemecahan berbagai permasalahan yang direkomendasikan oleh FKPM; d. Unsur Pelaku Bisnis. Pelaku bisnis (Pengusaha) merupakan salah satu komponen yang dapat mendukung persediaan dana yang sifatnya tidak mengikat serta dapat menyediakan sumber daya manusia dalam bentuk tenaga sekuriti dan pengamanan swakarsa; e. Lembaga-lembaga lain. Lembaga-lembaga lain seperti: Perguruan Tinggi, Sekolah, Rumah Sakit, Penyedia Jasa Sosial, Pusat Kesehatan Mental dan Lembaga Swadaya Masyarakat, dapat menjadi penyedia berbagai jasa pendukung bagi kelancaran dan keberhasilan Polmas, serta f. Media. Media merupakan komponen yang tidak kalah penting yang dapat membantu mendidik masyarakat agar menjadi mitra aktif polisi. Media juga penting dalam mendorong pembentukan opini masyarakat dan mengekspos peranserta masyarakat dalam FKPM.

\section{Arah dan Kebijakan Polmas}

a. Tujuan Penerapan Polmas

Tujuan penerapan Polmas adalah terwujudnya kerjasama Polisi dan masyarakat lokal (komunitas) untuk menanggulangi kejahatan serta ketidaktertiban sosial dalam rangka menciptakan ketentraman umum dalam kehidupan masyarakat setempat.

Selain itu juga menanggulangi kejahatan dan ketidaktertiban sosial mengandung makna bukan hanya mencegah tumbuhnya tetapi juga mencari jalan keluar pemecahan permasalahan yang dapat menimbulkan gangguan terhadap keamanan dan ketertiban yang bersumber dari dalam komunitas itu sendiri serta dalam batas-batas tertentu mengambil tindakan pertama jika terjadi kejahatan atau bahkan menyelesaikan pertikaian antar warga sehingga tidak memerlukan penanganan melalui proses formal dalam sistem peradilan pidana.

Ketiga adalah menciptakan ketentraman umum mengandung makna bahwa yang dituju oleh Polmas bukan hanya sekedar ketiadaan gangguan faktual terhadap keamanan dan ketertiban tetapi juga perasaan takut warga dalam kehidupan bersama dalam komunitas mereka.

Selain ketiga hal tersebut di atas, tujuan penerapan Polmas juga sebagai kerjasama polisi dan masyarakat mengandung makna bukan sekedar bekerja bersama dalam operasionalisasi penanggulangan kejahatan dan ketidaktertiban sosial tetapi juga meliputi mekanisme kemitraan yang mencakup keseluruhan proses manajemen mulai dari perencanaan sampai pengawasan/pengendalian dan analisis atau evaluasi atas pelaksanaannya. Karena itu strategi suatu tujuan kerja sama tersebut merupakan proses yang terus menerus tanpa akhir.

\section{b. Sasaran Penerapan Polmas}

Untuk memungkinkan terbangunnya kerjasama yang menjadi tujuan penerapan Polmas maka sasaran yang harus dicapai adalah membangun Polri yang dapat dipercaya oleh warga setempat dan membangun komunitas yang siap bekerjasama dengan Polri dalam meniadakan gangguan terhadap keamanan dan ketertiban serta menciptakan ketentraman warga setempat.

Polri yang dapat dipercaya tercermin dari sikap dan perilaku segenap personel Polri, baik dalam kehidupan pribadi sebagai bagian dari komunitas maupun dalam pelaksanaan tugas mereka, yang menyadari bahwa warga komunitas adalah stakeholder kepada siapa mereka dituntut untuk menyajikan layanan kepolisian sebagaimana mestinya.

Komunitas yang siap bekerja sama adalah kesatuan kehidupan bersama warga yang walaupun dengan latar belakang kepentingan yang berbeda memahami dan menyadari bahwa kepentingan penciptaan situasi keamanan dan ketertiban umum merupakan tanggung jawab.

c. Kebijakan Penerapan Polmas

Sebagaimana diutarakan sebelumnya, Polisi Masyarakat bukan hanya semacam program dalam penyelenggaraan fungsi kepolisian tetapi merupakan suatu metafora yang menuntut perubahan yang mendasar ke arah personalisasi penyajian layanan kepolisian. Perubahan demikian sudah barang tentu akan membawa konsekuensi dalam pelaksanaan tugas Polri sebagai aparat penegak hukum dalam suatu masyarakat demokratis yang menjunjung tinggi supremasi hukum. Kebijakan dasar yang diletakkan dalam penerapan Polmas hanya direalisasikan pada level lokal terutama lingkungan komunitas yang mencerminkan kehidupan bersama yang komunitarian.

Penerapan Polmas secara lokal tidak berarti bahwa prosesnya hanya dilakukan terbatas pada tataran operasional tetapi berlandaskan pada kebijakan yang komprehensif mulai tatanan konseptual pada level manajemen puncak. Pendekatan yang bersifat komprehensif maka kebijakan penerapan Polmas menyangkut bidang organisasi, manajemen sumber daya manusia, manajemen logistik, dan manajemen anggaran atau keuangan serta manajemen operasional kepolisian. 


\section{Tugas dan Kemampuan Petugas Polmas}

Tugas Pokok daripada petugas Polmas yaitu melaksanakan tugas dan fungsi-fungsi operasional kepolisian yang berkaitan dengan operasionalisasi Polmas serta mendorong berfungsinya pranata Polmas dalam rangka menyelesaikan setiap permasalahan atau gangguan keamanan dan ketertiban yang terjadi dan/ atau bersumber dari dalam lingkungan masyarakat setempat.

Dari tugas pokok tersebut dapat dijabarkan tugasnya meliputi: a. Mengidentifikasi dan mendokumentasi data sosial kemasyarakatan yang berkaitan dengan kondisi kamtibmas setempat; b. Membuat; mempelajari dan menguasai instrumen atau perangkat Kamtibmas meliputi Peta Kamtibmas (melukiskan kondisi konkrit dari Kelurahan/Desa seperti Jumlah Penduduk, sekolah, tempat ibadah, kegiatan rutin, masyarakat); Peta Topografi (melukiskan tanda-tanda berupa bangunan jalan, gunung, sungai, dan lain-lain); Peta Kriminalitas (melukiskan jumlah kejahatan yang terjadi dalam 1 sampai 5 tahun serta daerah rawan terjadi kejahatan termasuk juga tempat tinggal pelaku); Peta Lalu Lintas (melukiskan lokasi rawan kemacetan, pelanggaran dan kecelakaan Ialu lintas); Peta Rute Patroli (melukiskan jalur yang dilalui untuk kegiatan Patroli Kepolisian); 3) Melaksanakan fungsi bimbingan dan penyuluhan masyarakat yang meliputi: penyebarluasan informasi tentang kebijakan Pimpinan Polri dan misi Polri sehingga terbentuk opini publik yang positif, memberikan penyuluhan kepada warga agar timbul kesadaran terhadap hukum dan ketertiban; meyakinkan dan menghimbau warga untuk tidak melibatkan diri dalam kegiatan massa atau aktivitas yang bersifat anarkis dan melanggar hukum; 4) Melaksanakan tugas-tugas kepolisian umum seperti: patroli secara rutin pada wilayah penugasannya, mengambil langkah-langkah pengaturan atau pengamanan kegiatan masyarakat untuk menjamin ketertiban lalu lintas; melaksanakan kunjungan ke masyarakat untuk mendengarkan informasi ataupun keluhan warga masyarakat tentang pelayanan kepolisian dan membedakan pemahaman dan jalan keluar penyelesaian bila diperlukan, dan lain-lain. Wewenang petugas polmas meliputi mengambil tindakan kepolisian secara proporsional dalam hal terjadi perbuatan melawan hukum yang dipandang perlu, berkoordinasi dengan petugas kepolisian yang berkepentingan atau berwenang mengambil alih penanganannya.

Selain itu juga menyelesaikan perkara ringan atau pertikaian antar warga berdasarkan kesepakatan bersama antar pihak yang berperkara dan bila diperlukan bersama FKPM; serta mengambil langkah-langkah ketertiban jika diperhatikan sebagai tindak lanjut kesepakatan FKPM dalam memelihara keamanan lingkungan.

\section{EFEKTIFITAS KONSEP POLMAS DALAM MENCIPTAKAN KAMTIBMAS YANG KON- DUSIF \\ Pembentukan FKPM}

Sebagai tindak lanjut dari program Perpolisian Masyarakat tersebut yang telah diuraikan di atas maka perlu dibentuklah suatu wadah atau organisasi guna operasionalisasi Perpolisian Masyarakat tersebut. Wadah tersebut dapat berupa, FKPM (Forum Kemitraan Polisi dan Masyarakat). FKPM adalah suatu organisasi kemasyarakatan yang bersifat independen, mandiri dan dalam kegiatannya bebas dari campur tangan pihak manapun. FKPM tersebut dapat disebut dengan nama dan istilah lain atau dengan bahasa daerah tertentu atas dasar kesepakatan masyarakat setempat. FKPM dibangun atas dasar kesepakatan bersama antara Kapolsek, Camat/Kepala, Desa/Lurah dan tokoh masyarakat setempat.

FKPM mempunyai tugas pokok yaitu melaksanakan kegiatan-kegiatan yang berkaitan dengan operasionalisasi Perpolisian Masyarakat dan mendorong berfungsinya pranata Perpolisian Masyarakat dalam rangka menyelesaikan setiap permasalahan gangguan keamanan dan ketertiban yang terjadi dan atau bersumber dari dalam kehidupan masyarakat setempat. Dari uraian tugas pokok tersebut dapat dijabarkan pelaksanaan tugasnya meliputi menampung keluhan atau pengaduan masyarakat yang berkaitan dengan masalah kejahatan atau pelanggaran dan permasalahan kepolisian pada umumnya serta membahasnya (bila perlu memberdayakan warga yang berkompeten atau konsultan) permasalahan sosial aspek kamtibmas dalam wilayah atau bersumber dari wilayahnya dan menemukan akar permasalahan serta menentukan jalan keluar pemecahannya.

Di samping tugas pokok tersebut di atas, FKPM juga mempunyai wewenang yaitu membuat kesepakatan tentang hal-hal yang perlu dilakukan atau tidak dilakukan oleh warga sehingga merupakan suatu peraturan total dalam lingkungannya; secara kelompok atau perorangan mengambil tindakan kepolisian (upaya paksa) dalam hal terjadi kejahatan atau tindak pidana dengan tertangkap tangan, memberikan pendapat dan saran kepada Kapolsek baik tertulis ataupun lisan mengenai pengelolaan atau peningkatan kualitas keamanan atau ketertiban lingkungan; menegakkan peratuan lokal dan turut serta menye- 
lesaikan perkara ringan atau pertikaian antar warga yang dilakukan petugas Polmas.

\section{Keefektifan Konsep Polmas}

Konsep Perpolisian Masyarakat melalui Surat Keputusan Kapolri No. Pol: Skep/737/X/2005 tanggal 13 Oktober 2005 tentang Kebijakan dan Strategi Penerapan Model Perpolisian Masyarakat dalam penyelenggaraan tugas Polri dan turunannya berupa Surat Keputusan Kapolri No. Pol: Skep/433/VII/2006 tanggal 01 Juli 2006 tentang Panduan Pembentukan dan Operasionalisasi Perpolisian Masyarakat; secara sistematik akan menjadi angan-angan kosong belaka jika tidak disertai komitmen dan kerja keras untuk merealisasikannya. Karena itu diharapkan seluruh anggota Polres Surabaya Selatan mulai tingkat bawah sampai pucuk pimpinan bisa menerapkannya dalam pelaksanaan tugas dan kehidupan sehari-hari, walaupun tidak segampang membalikkan telapak tangan di Polres Surabaya Selatan sendiri penerapan Perpolisian Masyarakat dapat bersifat internal dan eksternal.

Internal arah penerapan kebijakan Perpolisian Masyarakat adalah ke dalam dengan sasaran seluruh jajaran kepolisian di wilayah hukum Polres Surabaya Selatan, sesuai tingkat jurisdiksinya dengan maksud membangun pemahaman tentang Perpolisian Masyarakat secara baik dan benar. Guna menarik simpati masyarakat dalam memberikan perlindungan, pengamanan dan pelayanan kepada masyarakat, anggota Polri harus menunjukkan perilaku terpuji dan menghindari perbuatan yang tercela serta menjaga performa secara fisik, kesatuan juga dituntut untuk menampilkan kinerja kepolisian secara totalitas. Khusus internal anggota Polres Surabaya Selatan perlu dikembangkan sikap mawas ke dalam untuk membangun kemitraan, meliputi: a. Penyamaan visi, persepsi dan interprestasi tentang perlunya kemitraan Polri dengan masyarakat; b. Memiliki cara berpikir yang positif (mission oriented, bukan provit oriented); c. Keyakinan dengan semangat kemitraan upaya pembinaan kamtibmas akan lebih efektif dan efisien; d. Pemahaman bahwa instansi dan masyarakat adalah mitra sejajar Polri dan tidak dipandang sebagai sumber potensial kriminalitas; e. Setiap anggota Polri harus mampu menampilkan cara bergaul yang dapat menarik simpati melalui 3S (senyum, sapa, dan salam), 3P (perhatian, pujian, dan penghargaan) dan 3PB (menjadi pendengar yang baik, penyela yang baik, pembicara yang baik); f. Memupuk jiwa kejujuran sikap keterbukaan dan perilaku menghargai orang lain dalam kehidupan sehari-hari; g. Setiap kesatuan dibentuk unit-unit anggota Polri yang punya keterampilan, sikap mental dan dedikasi tinggi dalam pelaksanaan tugas sebagai contoh bagi anggota yang lain, untuk mengarah pada polisi profesional dan menarik rasa simpati masyarakat sehingga tergerak ikut berperan dalam pemeliharaan keamanan dan ketertiban masyarakat secara swakarsa.

Kegiatan awal yang telah dilakukan diantaranya memberikan sosialisasi pelatihan kepada seluruh anggota atau internal Polres Surabaya Selatan maupun yang berada di Polsek jajaran. Selain itu juga dilaksanakan pula sosialisasi atau penyuluhan ke eksternal dengan sasaran seluruh publik yang bertempat tinggal, bekerja menuntut pendidikan formal maupun nonformal, instansi di suatu kawasan, dan lain-lain. Mereka diajak untuk dapat sebagai polisi bagi dirinya sendiri. Tidak sebagai korban apalagi sebagai pelaku kejahatan dan tanggapan masyarakat terhadap program Perpolisian Masyarakat mendapat suatu apresiasi yang cukup baik. Ini terlihat dengan sudah dibentuknya FKPM sejumlah 229 di jajaran PoIres Surabaya Selatan dengan rincian 1 FKPM Kecamatan, 45 FKPM Kelurahan, 172 FKPM RW, 2 FKPM RT, dan 9 FKPM Kawasan yang diawaki oleh 57 petugas Polmas yang membawahi 57 kelurahan, yang tersebar di 11 Polsek jajaran Polres Surabaya Selatan FKPM tingkat kawasan tersebut di antaranya kawasan mall Tunjungan, kawasan mall Pakuwon Trade Centre, kawasan Malam Karah, kawasan PKL Kedung Doro, kawasan Terminal Joyoboyo, dan lain-lain.

Dari jumlah tersebut di atas 152 diantaranya sudah dikukuhkan baik oleh Kapolwiltabes Surabaya maupun oleh Kapolres Surabaya Selatan. Keanggotaan FKPM itu sendiri dapat dari semua gabungan elemen yang ada di masyarakat seperti tokoh agama, tokoh masyarakat tokoh pemuda, tokoh adat, Karang Taruna, LSM, Ibu PKK serta warga masyarakat lainnya yang mempunyai pengaruh besar di satu tempat yang bersangkutan. Keanggotaan tersebut tidak membedakan golongan, pekerjaan, suku, agama dan ras satu sama lainnya. Mereka duduk bersama dalam satu meja untuk mengidentifikasi akar permasalahan dan membantu menyelesaikan permasalahan termasuk konflik yang timbul dalam suatu masyarakatnya.

FKPM tersebut juga mempunyai hak dan kewajiban diantaranya berhak mendapatkan fasilitas baik materiil maupun non materill sesuai yang ditetapkan atas disepakati forum khusus, aparat desa dan dukungan warga. Serta juga berhak mendapat dukungan anggaran dari pemerintah sepanjang tercantum dalam program kerja untuk pemecahan masalah-masalah sosial dalam rangka pembinaan Kamtibmas dan peningkatan kualitas hidup masyarakat. Kewajiban ang- 
gota FKPM dapat berupa menjunjung tinggi hak asasi manusia dan menghormati norma-norma agama, adat atau kebiasaan dan kesusilaan masyarakat setempat; bersikap jujur dalam menjalankan tugas; tidak diskriminatif menyajikan layanan kepolisian dan tidak berpihak dalam menangani perselisihan atau pertikaian; mengutamakan kepentingan umum serta tugas di atas kepentingan pribadi; bersikap santun dan menghargai setiap orang serta bersikap dan berperilaku yang dapat menjadi contoh dan tauladan masyarakat.

Hal-hal yang dilarang dilakukan oleh anggota FKPM adalah diantaranya membentuk suatu satuan tugas atau Satgas; menggunakan atribut dan emblem (lambang simbol) Polri dalam organisasi forum; tanpa bersama petugas Polmas, menangani sendiri penyelesaian kasus kejahatan dan pelanggaran; dan melakukan tindakan kepolisian (upaya paksa) terhadap kasus kejahatan, kecuali dalam keadaan tertangkap tangan serta mengatasnamakan atau mengkait-kaitkan hubungan Polmas atau FKPM dalam melakukan kegiatan politik praktis.

Dalam mengadakan kegiatan pertemuan rutin atau mengidentifikasi dan memecahkan persoalan yang timbul dapat dilakukan di suatu tempat/ balai yang dinamakan Balai Kemitraan Polisi dan Masyarakat, kegiatan tersebut tidak harus diadakan dengan mewah yang harus ada makan dan minumnya akan tetapi cukup dengan duduk bersama satu meja (secara equal atau setara, tidak ada saling merasa lebih berkuasa) antara pihak yang bertikai dengan semua anggota FKPM, mengidentifikasi akar permasalahannya serta mencari jalan keluar terbaik bagi semua warga masyarakat. Hasil jalan keluar tersebut dituangkan pada surat kesepakatan bersama dengan disaksikan anggota FKPM, petugas Polmas dan saksi-saksi. Hasil dari kesepakatan tersebut selanjutnya dilaporkan secara berjenjang ke satuan atas mulai dari Kapolsek, sehingga operasionalisasi FKPM tersebut mendapat pengawasan langsung dari Pimpinan Polri mulai dari tataran bawah sampai atas serta tidak keluar dari koridor hukum yang sudah ditetapkan melatui Surat keputusan Kapolri No. Pol: Skep/737/X/2005 tanggal 13 Oktober 2005 tentang Kebijakan dan strategi penerapan model perpolisian masyarakat dalam penyelenggaraan tugas Polri dan turunannya.

Di samping telah dilaksanakan sosialisasi atau penyuluhan mengenai Polmas dan pembentukan FKPM, pada anggota masyarakat yang tergabung dalam FKPM juga telah diadakan kegiatan Out Ward Bound. Kegiatan Out Ward Bound tersebut dilaksanakan oleh Polwiltabes Surabaya dengan peserta dari MPM Polres jajaran tingkat Polwiltabes Surabaya setiap dua minggu sekali pada sabtu sore sampai minggu pagi. Inti dari kegiatan Out Ward Bound tersebut peserta yang ikut dihadapkan pada suatu permasalahan mulai dari orang-orang yang berada di sekelilingnya untuk saling mengenal satu sama lain. Setelah adanya pengenalan dari kegiatan akan timbul suatu kepercayaan pada mereka, satu persepsi satu sama lain serta kompak. Selanjutnya bila timbul suatu permasalahan mereka diharapkan untuk dapat mencari akar permasalahannya, serta mencari jalan keluar dari permasalahan tersebut.

Perkara ringan atau pertikaian antar warga yang dimaksud di antaranya: a. Pelanggaran sebagaimana diatur dalam buku ketiga KUHP; b. Tindak pidana ringan yang diancam dengan pidana penjara atau hukuman paling lama 3 (tiga) bulan atau denda sebanyak-banyaknya Rp. 7.500,- (tujuh ribu lima ratus rupiah); c. Kejahatan ringan sebagaimana diatur dalam KUHP diantaranya; pasal 302 tentang penganiayaan ringan terhadap hewan; pasal 352 tentang penganiayaan ringan terhadap manusia; pasal 364 tentang pencurian ringan; pasal 373 tentang penggelapan ringan; pasal 379 tentang penipuan ringan; pasal 482 tentang penadahan ringan; dan pasal 315 tentang penghinaan ringan; d. Pertikaian antar warga yang terjadi antara individu dengan individu, individu dengan kelompok ataupun kelompok dengan kelompok yang hanya termasuk dalam kasus tindak pidana ringan dan pelanggaran. Apabila tidak segera dan cepat ditangani dengan baik maka dapat mengakibatkan pertikaian menjadi berkembang besar, bahkan dapat terjadi konflik sosial yang melibatkan kelompok masyarakat yang mencakup suku, agama, ras dan antar golongan.

Tabel 1

Permasalahan yang berhasil dipecahkan di jajaran Polres Surabaya Selatan pada bulan Maret s/d Agustus 2010

\begin{tabular}{llc}
\hline No & \multicolumn{1}{c}{ Waktu } & $\begin{array}{c}\text { Permasalahan } \\
\text { yang Berhasil } \\
\text { Dipecahkan }\end{array}$ \\
\hline 1. & $\begin{array}{l}\text { Minggu I } \\
\text { (29 Maret s/d 05 April 2010) }\end{array}$ \\
2. & $\begin{array}{l}\text { Minggu II } \\
\text { (06 April s/d 12 April 2010) }\end{array}$ \\
3. $\quad \begin{array}{l}\text { Minggu III } \\
(13 \text { Mei s/d 19 Mei 2010) }\end{array}$ & 22 \\
4. $\quad \begin{array}{l}\text { Minggu IV } \\
\text { (20 Mei s/d 05 Agustus 2010) }\end{array}$ & 16 \\
\hline
\end{tabular}

FKPM yang berada di wilayah jajaran Polsek Surabaya Selatan hampir setiap minggunya telah berhasil mengidentifikasi dan mencarikan jalan keluar 
permasalahan. Dari jumlah di atas, maka rata-rata permasalahan yang berhasil dipecahkan yaitu: (Minggu I + Minggu II + Minggu III + Minggu IV $): 4=(22$ $+31+21+16): 2=22,5$

Jadi rata-rata sejumlah 22 (dua puluh dua) permasalahan yang berhasil diselesaikan setiap minggunya. Dengan adanya penyelesaian tersebut di tingkat masyarakat FKPM, maka tidak perlu lagi diselesaikan ke tingkat yang lebih tinggi. Secara tidak langsung kejahatan atau pelanggaran yang terjadi di masyarakat akan berkurang karena masyarakat karena meningkatnya kesadaran hukum masyarakat sehingga keamanan dan ketertiban masyarakat setempat akan kondusif. Diharapkan dengan adanya Perpolisian Masyarakat ini masyarakat ini akan dapat menjadi polisi bagi dirinya sendiri. Di samping itu masyarakat untuk tidak menjadi korban apalagi sebagai pelaku kejahatan.

Agar tetap sesuai dengan koridor hukum serta mudah dalam pengawasannya, maka Polres Surabaya Selatan melakukan kegiatan analisa dan evaluasi terhadap kegiatan-kegiatan yang telah dilakukan oleh petugas Polmas dan FKPM yang menjadi binaannya. Kegiatan tersebut dilaksanakan satu minggu sekali yaitu pada hari Selasa bertempat di Ruang Eksekutif Polres Surabaya Selatan. Pada forum tersebut dijadikan sebagai ajang saling tukar pendapat saling berbagi informasi baik dari pimpinan ke bawahan maupun sebaliknya serta dari Kelurahan satu dengan Kelurahan lainnya.

Keuntungan yang dapat diharapkan dengan adanya Perpolisian Masyarakat bagi Masyarakat diantaranya: 1) Komitmen terhadap pencegahan kejahatan Polmas berupaya untuk mempertegas misi dasar kepolisian dalam mencegah kejahatan dan ketidaktertiban; 2) Pengetahuan masyarakat tentang operasi-operasi yang dilakukan polisi karena masyarakat akan dilibatkan dalam tugas polisi secara terbatas, mereka akan menemui "apa", "mengapa" dan "bagaimana" Polisi bekerja. Keterlibatan tersebut sangat penting untuk mendorong adanya masukan-masukan dan diskusi kritis tentang kemampuan merespon dan efisiensi operasi kepolisian dalam menangani masalah-masalah masyarakat; 3) Tanggungjawab ke Publik: dalam Polmas, polisi juga mempertanggungjawabkan kegiatannya kepada masyarakat yang telah menjadi mitra; 4) Pelayanan polisi yang disesuaikan: karena petugas polisi berasal dari daerah setempat maka petugas dituntut untuk meningkatkan kemampuan merespon masalah-masalah di lingkungannya; 5) Organisasi masyarakat: tingkat keterlibatan masyarakat dan upaya-upaya polisi menangani masalah-ma- salah di lingkungannya memiliki efek yang signifikan terhadap efektifitas upaya-upaya tersebut dengan kata lain, kesuksesan pencegahan kejahatan tergantung pada polisi dengan masyarakat yang bekerja bersama-sama.

Keuntungan-keuntungan tersebut akan meyakinkan masyarakat bahwa mereka memiliki peran penting sebagai mitra polisi dalam mencegah dan menyelesaikan masalah-masalah yang terjadi di masyarakat. Keuntungan bagi polisi dengan adanya program Perpolisian Masyarakat diantaranya: a. Makin banyaknya informasi akan semakin dapat membantu dalam investigasi, penyelesaian kasus, penangkapan orang yang dicurigai; $b$. Bantuan dalam tugas-tugas operasional (pengawasan lingkungan) dan usaha-usaha pencegahan kejahatan; c. Memberikan panduan terhadap suatu masalah dan kejadian ketidaktertiban di masyarakat dari sudut pandang "akar rumput", guna meningkatkan pelayanan polisi; d. Membantu memecahkan masalah yang terjadi di masyarakat melalui Forum Kemitraan Polisi Masyarakat; e. Berbagi tanggung jawab terhadap pencegahan kejahatan dan keamanan publik; dan 6. Melalui Forum Kemitraan Polisi Masyarakat dapat membangun kemitraan dan kepercayaan masyarakat untuk meningkatkan citra polisi.

\section{Kesalahpahaman dan Indikator Keberhasilan Polmas}

Dari sekian banyak keuntungan yang didapatkan dari Perpolisian Masyarakat baik bagi masyarakat maupun polisi itu sendiri, di kacamata umum maupun internal polisi sendiri kadang-kadang masih adanya kesalahpahaman mengenai Perpolisian Masyarakat. Perpolisian Masyarakat bukanlah: "Suatu bagian atau divisi yang terpisah dalam Institusi Kepolisian, dan juga bukan merupakan tanggung jawab seorang anggota polisi saja". Terjadinya pemisahan divisi dari Polmas dapat menimbulkan kesalahpahaman yaitu Polmas hanyalah dianggap sebagai tugas polisi divisi tersebut semisal Binamitra saja sehingga staf divisi tersebut sajalah yang melaksanakannya. Oleh karena itu harus ditekankan bahwa Polmas tetap merupakan tanggung jawab dan setiap anggota polisi. Mulai dari yang berada di bagian admistrasi dan jajaran paling bawah sehingga pucuk pimpinan Polri merupakan mata rantai yang penting dalam Polmas. "Polmas bukanlah sebuah Teknik" yang dapat begitu saja diterapkan untuk memecahkan satu kejahatan atau ketidaktertiban tertentu dalam masyarakat. Polmas adalah satu cara berfikir dan bertindak yang baru dari kepolisian. Polmas adalah satu "strategi operasional" untuk keseluruhan organisasi kepoli- 
sian. Oleh sebab itu Polmas menuntut sikap dan pendekatan baru peran polisi anggota Polmas sanggup melaksanakan tugas-tugas Polmas dan tidak melihat kejahatan semata-mata sebagai insiden yang tidak saling terkait. Seluruh anggota kepolisian harus mengenal filosofi dan prinsip-prinsip Polmas. "Polmas bukanlah hubungan masyarakat (humas) atau sebuah program yang dirancang khusus untuk memperbaiki citra polisi". Hubungan yang baik dengan masyarakat dan perbaikan "citra" polisi hanyalah "efek samping" dan bukan tujuan utama. Strategi perpolisianlah yang membuat masyarakat menjadi "mitra" dalam memberantas kejahatan dan bekerja sama untuk mencegah masalah yang terkait dengan ketidaktertiban dalam masyarakat dan kejahatan. Polmas tidak bersifat "lunak" terhadap kejahatan. Dengan adanya informasi dari masyarakat seorang polisi dalam sebuah sistem Polmas akan menangkap orang lebih banyak. Polmas memungkinkan polisi menangani persoalan masyarakat yang lebih banyak sebagai tambahan dalam hal penegakan hukum, dan bukannya sebagai pengganti penegak hukum. Polmas dapat juga disebut sebagai perpolisian yang "lebih pintar" karena anggota polisi memahami menahan seseorang hanya merupakan salah satu solusi dari banyak cara pemecahan kejahatan dan ketidaktertiban dalam masyarakat. Anggota polisi dalam Polmas juga berkonsentrasi pada akar penyebab kejahatan dan ketidaktertiban untuk mencari jalan keluar yang permanen. Polmas bukan merupakan "pelayan sosial", tapi merupakan pekerjaan polisi "yang sesungguhnya". Memberantas kejahatan secara efektif tergantung dalam pola pengenalan bentuk akar permasalahannya. Dengan demikian Polmas berupaya untuk mengidentifikasi sebab-sebab tersebut dalam masyarakat. Oleh sebab itu, Polmas mendorong anggota polisi bersama masyarakat untuk fokus pada pemecahan masalah dan ketidaktertiban yang terjadi di dalam masyarakat. Demi mencapai tujuan tersebut, polisi dan masyarakat harus bersama-sama mengidentifikasi akar penyebab kejahatan dan ketidaktertiban yang terjadi di dalam masyarakat. Perluasan peran semacam ini sesuai dengan apa yang sudah lama dipahami anggota polisi, bahwa menangkap dan memenjarakan penjahat saja tidak akan menghentikan perilaku kejahatan. "Polmas bukan suatu obat mujarab". Tidak dapat dipungkiri memberantas akar penyebab kejahatan tidaklah mudah. Kita tidak boleh menganggap Polmas sebagai satu obat mujarab yang dapat segera menyelesaikan semua masalah dalam masyarakat. Sebagai seorang anggota polisi, kita harus memiliki satu pendekatan yang canggih, logis, tersamar, halus, dan fleksibel dengan fokus pada kejahatan dan ketidaktertiban yang terjadi di tingkat bawah (tingkat "akar rumput").

Dari uraian yang telah dijelaskan tersebut di atas, ada beberapa hal yang dapat dijadikan acuan atau indikator bahwa keberadaan Polmas di Polres Surabaya Selatan sangat dirasa tepat kehadirannya, berhasil dan efektif dalam penyelenggaraannya sebagai berikut: a. Intensitas kegiatan forum terbaik pengurus ataupun keikutsertaan warganya; b. Kemampuan forum untuk menemukan dan mengidentifikasi akar permasalahan; c. Kemampuan petugas Polmas bersama forum menyelesaikan permasalahan termasuk konflik atau pertikaian antar warga; d. Kemampuan mengakomodasi keluhan masyarakat; e. Intensitas dan ekstensitas kunjungan warga oleh petugas Polmas; f. Berkurangnya tingkat kejahatan secara menyeluruh; g. Kejahatan selama ini jarang dilaporkan, seperti pemerkosaan, kekerasan dalam rumah tangga dan pelecehan terhadap anak-anak. Apabila laporan jenis kejahatan ini meningkat dalam daftar laporan polisi, hal ini merupakan salah satu indikator meningkatnya kepercayaan masyarakat terhadap polisi. Hal ini terbukti dengan adanya penyelesaian permasalahan salah satunya kekerasan dalam rumah tangga yang telah diselesaikan Polmas di jajaran Polres Surabaya Selatan selama bulan Desember 2007 kurang lebih sekitar 13 permasalahan di samping permasalahan yang lainnya; h. Masyarakat memiliki persepsi yang lebih baik tentang Polisi; i. Berkurangnya keadaan yang memicu terjadinya kejahatan; j. Adanya komunikasi yang lebih baik antara Polisi dengan masyarakat; $\mathrm{k}$. Masyarakat turut bertanggungjawab terhadap terjadinya kejahatan; 1 . Adanya pelayanan polisi yang lebih baik dan profesional kepada masyarakat; $\mathrm{m}$. Kebersamaan dan kepuasaan masyarakat atas penerapan pranata Polmas.

\section{PENUTUP \\ Kesimpulan}

Dari uraian yang telah dijelaskan sebelumnya, dapat disimpulkan sebagai berikut:

a. Eksistensi Perpolisian Masyarakat yang merupakan strategi baru di tubuh kepolisian: (1) Pada hakekatnya bukan merupakan hal yang asing karena kebijakan Siskamswakarsa, yang diangkat dari nilai-nilai sosiokultural pada masyarakat Indonesia sudah ada sebelumnya. (2) Perpolisian Masyarakat harus dipahami sebagai persatuan sekaligus kesatuan dari 2 (dua) bagian yang berbeda tetapi tidak terpisahkan, yaitu polisi dan publik (anggota masyarakat yang bukan polisi). (3) Komponen utama, dan Perpolisian Masyara- 
kat terdiri dari 2 hal adalah pertama; Kemitraan yang sejajar antara Polisi dan Masyarakat (Equal Partnership); kedua; adalah Menyelesaikan berbagai masalah sosial yang terjadi dalam masyarakat lokal (Problem Solving). (4) Masyarakat diharapkan dapat menjadi polisi bagi dirinya sendiri; tidak menjadi korban apalagi pelaku kejahatan. (5) Forum Kemitraan Polisi Masyarakat sebagai salah satu pembentukan Perpolisian sebagai "jantung" "motor penggerak" "ujung tombak" Perpolisian Masyarakat; dimana dinamika demokrasi yang berkenaan dengan perpolisian berlangsung. Posisi FKPM berada di tengah masyarakat dalam penyelenggaran Perpolisian Masyarakat.

b. Perpolisian Masyarakat mampu menciptakan kamtibmas yang kondusif, indikatornya adalah kemampuan forum untuk menemukan dan meng identifikasi akar permasalahan, kemampuan petugas Polmas bersama forum menyelesaikan permasalahan termasuk konflik atau pertikaian antar warga, berkurangnya tingkat kejahatan atau secara menyeluruh serta meningkatnya laporan terhadap kejahatan yang selama ini jarang dilaporkan seperti kekerasan dalam rumah tangga.

\section{Rekomendasi}

Berdasarkan kesimpulan di atas, disarankan sebagai berikut:

a. Mengingat strategi baru, jadi masih banyak dari internal polisi maupun masyarakat yang belum paham atau kesimpangsiuran tentang Perpolisian Masyarakat; maka dari itu sosialisasi serta pelatihan-pelatihan kepada internal polisi serta sosialisasi dan penyuluhan kepada masyarakat dilakukan agar terdapat kesatuan persepsi.

b. Disarankan untuk mendapat dukungan dari semua pihak, baik polisi itu sendiri, masyarakat maupun dari instansi lain seperti dari Lembaga Swadaya Masyarakat (LSM), media massa, dan lain-lain agar Perpolisian Masyarakat dapat berjalan dan berhasil dengan baik sesuai dengan yang diharapkan.

c. Setiap anggota Polri dalam tampilan di tempat umum menunjukkan sikap dan perilaku yang baik serta dalam kehidupan di lingkungan kerja senantiasa berupaya membangun hubungan yang harmonis dalam rangka menumbuhkan kepercayaan masyarakat terhadap Polri.

d. Membentuk Forum Kemitraan Polisi Masyarakat sebagai wadah kerjasama antara polisi dengan masyarakat yang mengoperasionalkan Polmas dalam lingkungannya. e. Membentuk jaringan koordinasi dan kerjasama antara Forum Kemitraan Polisi Masyarakat dengan kesatuan Polri dalam hal ini Polres termasuk memantau, mengawasi atau mengendalikan, memberikan bimbingan teknis dan arahan serta melakukan penilaian atas keefektifan program Perpolisian Masyarakat.

\section{DAFTAR PUSTAKA}

\section{Buku:}

Bachtiar, Harsya W., 1994, llmu Kepolisian, Jakarta: Penerbit Grasindo.

Chumaisa, Sri, 2006, Perpolisian Masyarakat, Surabaya: Semeru Polda Jatim.

Kapolda, Kebijakan dan Strategi Penerapan Model Perpolisian Masyarakat dalam Penyelenggaraan Tugas Polri, Surat Keputusan, Oktober 2005.

Kapolri, Panduan Pelaksanaan Fungsi Intelkam, Reskrim, Samapta, Lalu Lintas, PolAir, Brimob dengan Pendekatan Perpolisian Masyarakat, Surat Keputusan, Juli 2006.

Kapolri, Panduan Pembentukan dan Operasionalisasi Perpolisian Masyarakat, Surat Keputusan, Juli 2006.

Kapolri, Pedoman Pembinaan Personel Pengemban Fungsi Perpolisian Masyarakat, Surat Keputusan, Juli 2006.

Mabes Polri, 1999, Reformasi Menuju Polri yang Profesional, Jakarta: Mabes Polri.

Meliala, Adrianus, 2004, Community Policing, Surabaya: Semeru Polda Jatim.

Pokja Polri-IOM, Perpolisian Masyarakat, Mabes Polri-Jakarta, 2006.

Sparingga, Daniel, 2006, Merubah Diri dari Militeristik menjadi Civil Police, Surabaya: Semeru Polda Jatim.

\section{Peraturan Perundang-undangan:}

Pembukaan Undang-Undang Dasar RI 1945.

Undang-Undang Republik Indonesia No. 2 Tahun 2002 tentang Kepolisian Negara Republik Indonesia.

\section{Media Massa:}

Majalah Semeru No. 338 Edisi Nopember 2004.

Majalah Semeru No. 352 Edisi Januari 2006.

Majalah Semeru No. 358 Edisi Juli 2006.

Majalah Semeru No. 359 Edisi Agustus 2006. 